\title{
Impact of processing temperature on drying behavior and quality changes in organic beef
}

\author{
Von Gersdorff, G. J. E.*; Shrestha, L.; Raut, S.; Retz, S. K.; Hensel, O.; Sturm, B. \\ a Department of Agricultural \& Biosystems Engineering, University of Kassel, Witzenhauen, \\ Germany
}

*E-mail of the corresponding author: g.gersdorff@uni-kassel.de

\begin{abstract}
The drying of beef has gained an increasing interest and the organic market shows an increasing demand for dried beef products. In this study, organic beef meat slices were dried at $50{ }^{\circ} \mathrm{C}, 60^{\circ} \mathrm{C}$ and $70^{\circ} \mathrm{C}$. Moisture content and color was measured throughout the drying process alongside Vis/VNIR hyperspectral images of the slices. The results of the total color difference $(\Delta E)$ showed the biggest change for samples dried at $50{ }^{\circ} \mathrm{C}(\Delta E=25.6)$. The $a_{w}$ value was the lowest for slices dried at $50^{\circ} \mathrm{C}(0.744)$. The hyperspectral data gave promising results regarding non-invasive prediction of moisture content and color.
\end{abstract}

Keywords: beef drying; drying behavior;color; hyperspectral imaging; quality. 


\section{Introduction}

The dehydration of meat has a long tradition as a preservation method and is still an option in areas where no refrigeration is available. Meat is a valuable protein source. However, a high protein and water content is exactly the reason why meat is also very perishable product and meat is often linked to foodborne disease [1-4]. There are various options for dehydration, e.g. whole muscles or parts of the muscles, which are very common as intermediate meat products such as ham or are known as biltong in South Africa and need to be sliced into bite-sized pieces after drying. Further examples for dried meat products are jerky from the USA and charqui from countries of South America which are cut to thin slices even before drying. While charqi is usually an important ingredient for daily meals and is rehydrated by cooking, jerky is a typical ready-to-eat snack food. There are neither restrictions regarding the meat variety (beef, pork, chicken etc.), nor regarding the varieties of spices that are added before drying (salt, pepper, honey, etc.). Further, smoking can present a post-drying processing step, but have been shown to influence the drying behavior, while the final product color is not influenced $[5,6]$.

In organic processing, the food additives are highly restricted and the processing itself is the main factor to gain high quality products. In this paper, beef was dried at 50,60 and $70{ }^{\circ} \mathrm{C}$ to a jerky style product to investigate the influence on the final product quality. Drying behavior and development of color were investigated The reflectance of the samples was detected by hyperspectral imaging to investigate the option of implementation of noninvasive control systems into beef drying.

\section{Materials and Methods}

\subsection{Meat type}

For the experiment the roast beef (longissimus dorsi) of 426 months old heifers carcass weight $320 \mathrm{~kg}$ ) of Uckermarker breed was used which led to four repetitions for each drying temperature. The beef was shock frozen 2 days after slaughter and stored at $-18{ }^{\circ} \mathrm{C}$ until use. $24 \mathrm{~h}$ before each drying experiment, the beef was thawed at $4{ }^{\circ} \mathrm{C}$ for $24 \mathrm{~h}$.

\subsection{Sample preparation}

The thawed beef was sliced with an electrical slicer (Graef, Allesschneider Vivo V 20, Arnsberg, Germany) with the fiber to slices of five mm thickness and cut to $50 \times 50 \mathrm{~mm}$ samples with a knife. The initial weight was determined with a lab balance (lab scales, E2000D, Sartorius, Göttingen, Germany), further the color was determined with a Chroma Meter CR-400 (Minolta, Osaka, Japan) measured on three spots per sample and expressed using the CIELAB color space. Eight slices were used per repetition, four were dried in an oven (SLE 500, Memmert GmbH, Germany) at $105{ }^{\circ} \mathrm{C}$ for 24 hours after the drying 
process to calculate the initial and final moisture content, the remaining samples were analysed with a water activity meter (LabSwift. Novasina, Lachen, Switzerland) to determine their $\mathrm{a}_{\mathrm{w}}$-values.

\subsection{Drying process}

The samples were dried at 50, 60 and $70{ }^{\circ} \mathrm{C}$ in a hot air tray dryer (HT mini, Innotech Ingenieursgesellschaft mbH, Germany). The samples were weight and the color was determined invasively by taking the samples out of the dryer every 20 minutes for the first hour of drying, in a 30 min interval for the second hour and hourly afterwards. Based on an estimated initial moisture content of $73 \%$, the drying process was stopped after 420 min for the drying temperature of $70{ }^{\circ} \mathrm{C}$, after $480 \mathrm{~min}$ at $60{ }^{\circ} \mathrm{C}$ and after $600 \mathrm{~min}$ at $50{ }^{\circ} \mathrm{C}$.

\subsection{Calculations}

Based on the weighing during drying and after oven drying for 24 hours, the moisture content (MC) on the dry basis was calculated and the moisture ratio (MR) was determined with the following equation (simplified by Rayaguru and Routray (2012) [7]):

$$
M R=\frac{M}{M_{i}}
$$

With $M_{t}$ and $M_{t+\Delta t}$ as moisture content in $\mathrm{gH}_{2} \mathrm{O} / \mathrm{gDM}$ at time $t$ and $t+\Delta t$ and the time in hours. The color change $\Delta \mathrm{E}$ at every time of measurement compared to the initial color was calculated by:

$$
\Delta \mathrm{E}=\sqrt{\left(\mathrm{L}_{\mathrm{i}}-\mathrm{L}_{\mathrm{t}}\right)^{2}+\left(\mathrm{a}_{\mathrm{i}}^{*}-\mathrm{a}_{\mathrm{t}}^{*}\right)^{2}+\left(\mathrm{b}_{\mathrm{i}}^{*}-\mathrm{b}_{\mathrm{t}}^{*}\right)^{2}}
$$

with $i$ representening the initial $\mathrm{L}$-, $\mathrm{a}^{*}$ - and $\mathrm{b}^{*}$-values and $t$ the values for color at every time.

\subsection{Hyperspectral imaging}

The samples were also imaged with an hyperspectral camera before and during drying in the intervals mentioned above. The visible near-infrared (VNIR) hyperspectral imaging systems consists of an ImSpector V10E PFD camera coupled to a linear translation stage (SPECIM Spectral Imaging Ltd., Finland). $27 \mathrm{~cm}$ above the belt conveyor tray (working speed $8 \mathrm{~mm} / \mathrm{s}$ ) a $35 \mathrm{~mm}$ lnes (Xenoplan 1.9/35, Schneider Optische Werke GmbH, Germany) was positioned, which resulted in a spatial area of $0.03 \mathrm{~mm}^{2}$ per pixel. This setting allowed to capture spectral data of $400-1010 \mathrm{~nm}$ in $1.5 \mathrm{~nm}$ increments. More details, including the image processing with Matlab software package (Matlab R2013a) are described by Crichton et al. (2017 a,b) [8,9], Retz et al. (2017) [10] and von Gersdorff et al. (2018) [6]. 


\section{Results and Discussion}

\subsection{Drying behavior and water activity}

The drying curves of beef dried at 50,60 and $70^{\circ} \mathrm{C}$ are illustrated in Figure 1 a), further Figure $1 \mathrm{~b}$ ) represents the drying rate (DR). As compared to Başlar et al. (2014) [6], who investigated the drying of beef with three different drying methods at 55,65 and $75^{\circ} \mathrm{C}$, the beef dried the fastest at the highest temperature due to a higher heat and mass transfer at higher temperatures [7]. The MR decreases exponentially, with is in accordance with other raw materials e.g. pumpkin [8], diverse vegetables [9] and apples [10], only to mention a few, and can be explained by a high heat and mass transfer coefficient during surface evaporation [7] in the initial stage of drying. During drying, the flux of moisture from the inside to the surface decreases and is smaller than the evaporation on the surface [11]
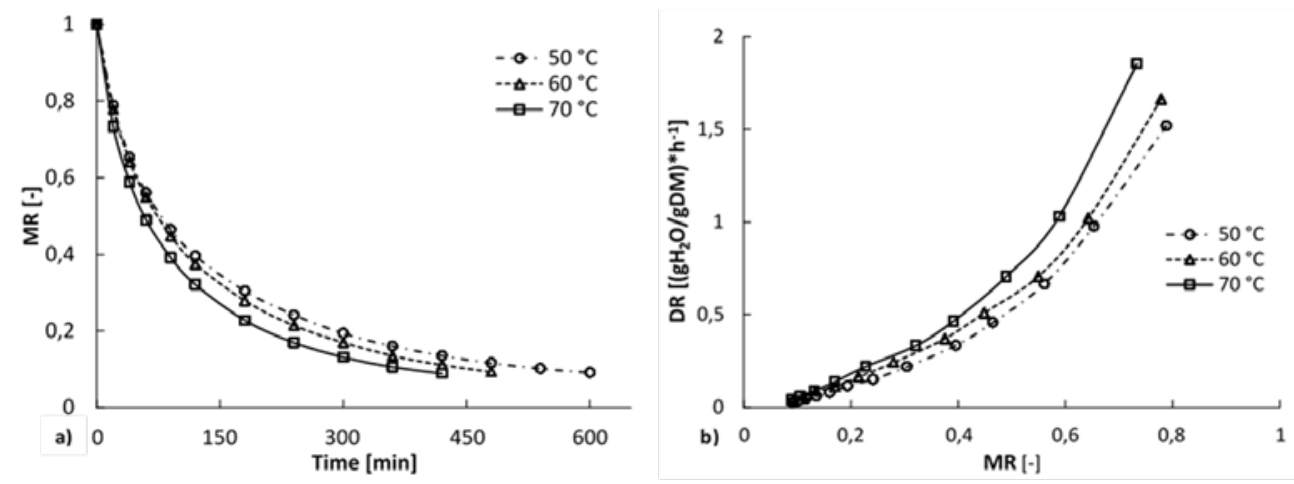

Figure 1: Drying curves of beef dried at 50, 60 and $70^{\circ} \mathrm{C}$ a) and related drying rates (DR) Figure

1b)

However, the distance between the drying curves of 70 and $60{ }^{\circ} \mathrm{C}$ is obviously bigger than between 60 and $50{ }^{\circ} \mathrm{C}$. This can be explained by a significantly higher drying rate of beef during drying at $70{ }^{\circ} \mathrm{C}$, which becomes clearer by illustrating the drying rate (DR) as a function of moisture ratio (MR) (Figure $1 \mathrm{~b}$ ). With $1.85\left(\mathrm{~g} \mathrm{H}_{2} \mathrm{O} / \mathrm{g} \mathrm{DM}\right) * \mathrm{~h}^{-1}$ beef dried at 70 ${ }^{\circ} \mathrm{C}$ shows the highest DR after 20 min of drying and a MR of 0.73 , but decreases rapidly with the decreasing MR during drying. The distance between the three DR curves decreases during drying and at low MRs the DR is nearly the same regardless of the temperature applied. This might be an effect of the decreasing heat and mass transfer mentioned above, but also struchtural changes (e.g. protein denaturation) might occur during protein and collagen denaturation[12,13] which effects the transfearability of water.

The water activity was $0.753( \pm 0.047)$ for beef dried at $50{ }^{\circ} \mathrm{C}, 0.762( \pm 0.034)$ for $60{ }^{\circ} \mathrm{C}$ and 0.763 ( \pm 0.038 ) for $70{ }^{\circ} \mathrm{C}$. Therefore, all the samples are safe from growth of the most 
bacteria and from mycotoxin production of mold and yeasts $\left(\mathrm{a}_{\mathrm{w}} \leq 0.85\right)$ [4], and although the $50{ }^{\circ} \mathrm{C}$ samples showed the lowest water activity, the highest standard deviation indicate not a significant influence between the drying temnperatures.

\subsection{Development of color}

The development of $\mathrm{L} \mathrm{a}^{*}$ and $\mathrm{b}^{*}$ values and the related change of color during drying is illustrated in Figure 2 a)-d). The graphs show that meat is not a homogenous product which is expressed in different values for CIELAB data before any heat treatment was applied at point 0 . The development for $\mathrm{L}$ values for beef dried at 60 and $70{ }^{\circ} \mathrm{C}$ is very similar, the lightness of beef dried at $50{ }^{\circ} \mathrm{C}$ decreases more during the whole drying process compared to the dehydration at $70^{\circ} \mathrm{C}$. The development of the lightness seems to be linked directly to the moisture content, while the redness (Figure 2b) develops unequal for different dehydration temperatures until a certain moisture content is reached. Those investigations are not in line compared to drying of ostrich jerky, where the drying air temperature was found to have an influence and not the moisture content [14] and needs further investigations. An air temperature of $50{ }^{\circ} \mathrm{C}$ seem to retain the red color better, expressed in a slight increase in redness
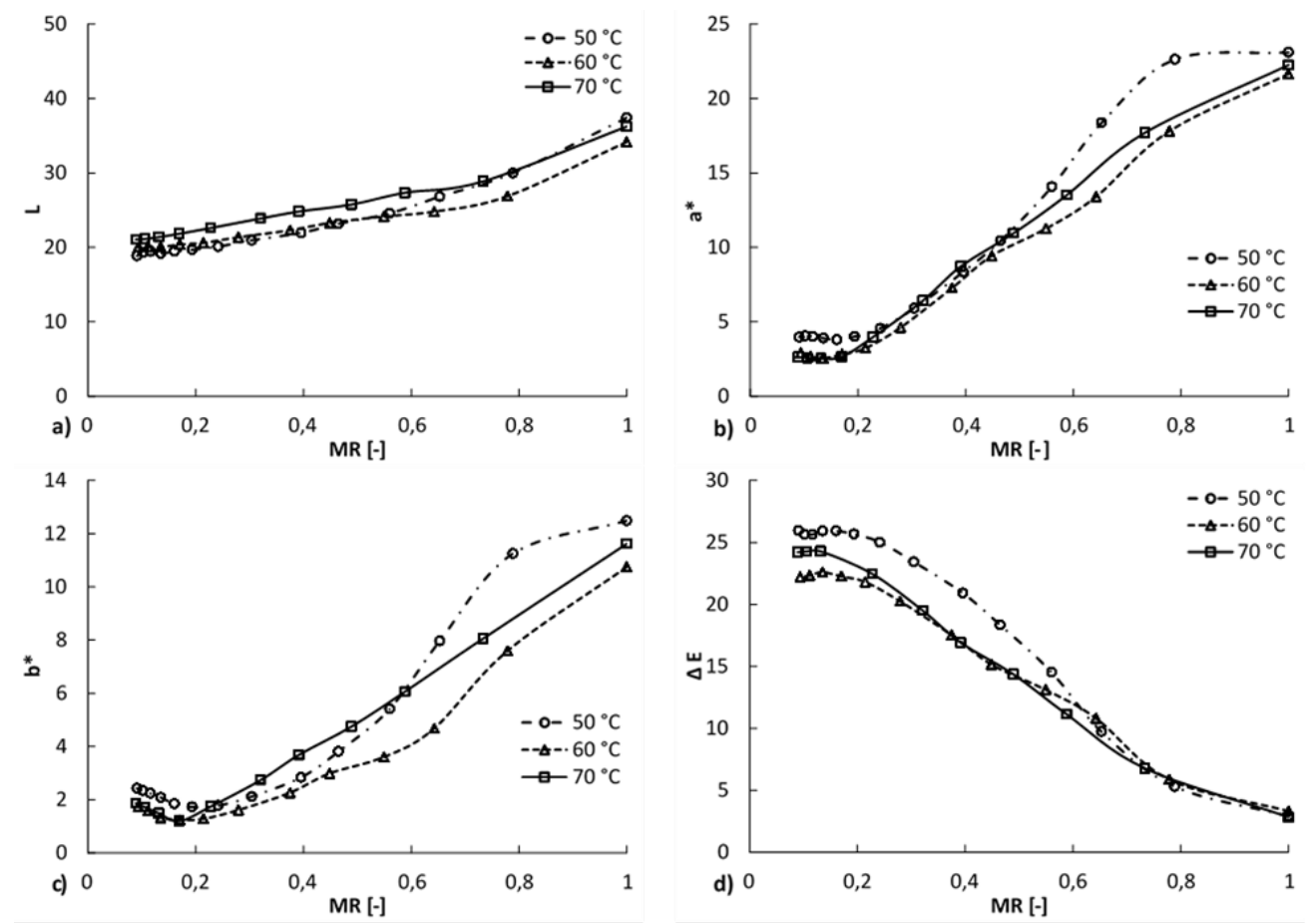

Figure 2: Development of $L$ - $a^{*-}$ and $b^{*}$-values during drying og beef a 50, 60 and $70{ }^{\circ} \mathrm{C}(\mathrm{a}-\mathrm{C})$ and corresponding color change $\triangle E$ as functions of $M R$. 
compared to the 60 and $70{ }^{\circ} \mathrm{C}$, however, the initial a-value might be the influencing factor for the final redness. The yellowness is not an indicator of moisture content at higher moisture contents, as it develops very different throughout the three drying temperatures until a low moisture content is reached and the $b^{*}$-value develops nearly the same from a certain point on for all three drying temperatures. Regarding the the total color change $(\Delta \mathrm{E})$, beef samples dried at $50{ }^{\circ} \mathrm{C}$ changes the most in color, while samples dried at $60{ }^{\circ} \mathrm{C}$ showed the lowest change related to the initial color. For all samples the color stops changing at a low moisture content. However, usually the drying should be as short as possible, as long drying periods may influence both the energy efficiency and the quality parameters negatively [15], which might explain the higher $\Delta \mathrm{E}$ for the $50^{\circ} \mathrm{C}$ processing. The second highest $\Delta \mathrm{E}$ for samples dried at $70{ }^{\circ} \mathrm{C}$ might be explained by the denaturation of proteins due to heat treatment $[12,16]$. However, the non-invasive measurements might also have an influence on the color development due to the differences in temperature (cooling during measurements, heating up in the drying intervals).

\subsection{Hyperspectral imging}

The relative reflectance of raw beef, dried for $120 \mathrm{~min}$ at 50,60 and $70^{\circ} \mathrm{C}$ and beef dried to the final moisture content is shown in Figure 3. The reflectance of beef is at the highes level in the visible spectral region in the red range due to the red color of the beef, mwhich was documented by Wu et al. (2013) [17] before.

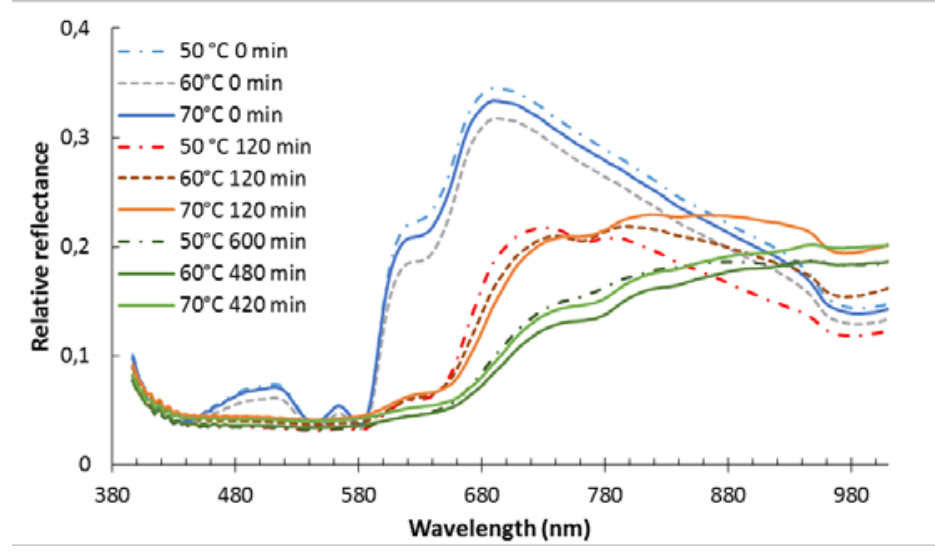

Figure 3: Relative reflectance of beef dried at 50, 60 and $70^{\circ} \mathrm{C}$ air temperature after 0 and 120 minutes of dehydration and at final moisture content.

The reflectance is decreasing over time which is reasoned by the decreasing moisture content during dehydration. Further, both, the visible and the NIR region of the spectrum affects the relative reflectance. The drying temperature affects the reflectance during drying (120 minutes) in particular in the NIR region, samples dried to the final moisture content show nearly the same reflectance, regardless of the drying air temperature, which might be 
due to different moisture contents after the same time after drying at different temperatures. However, differences in reflectance spectra do not necessarily affect the successful implementation of color and moisture content prediction models like shown for apple drying [8].

\section{Conclusion}

The present investigations show the shortest drying time for the highest drying time, but there are indications, that drying a lower air temperature might save quality attributes better, while too low temperatures again might influence the quality negatively. As quality indicator, final color shows minor changes for beef dried at $60{ }^{\circ} \mathrm{C}$ compared to $50{ }^{\circ} \mathrm{C}$ and $70^{\circ} \mathrm{C}$. However, the difference in color was not visible with the bare eye and might further be negatively influenced by the invasive measurements which needs further research. The spectral results will be further investigated and used to build prediction models to test the useful implementation of simplified non-invasive sensors.

\section{Acknowledgements}

The Authors wish to thank the Core Organic Plus Programme for the financial support within the SusOrganic project (Project Number: BLE - 2814OE006), and the SusOrgPlus Project (Project Number: BLE - 2817OE005) and the Reload Project (Project No.: BMBF 031A247A).

\section{References}

[1] Nemser, S.M.; Doran, T.; Grabenstein, M.; McConnell, T.; McGrath, T.; Pamboukian, R.; Smith, A.C.; Achen, M.; Danzeisen, G.; Kim, S.; Liu, Y.; Robeson, S.; Rosario, G.; Wilson, K.M.; Reimschuessel, R. Investigation of Listeria, Salmonella, and Toxigenic Escherichia coli in Various Pet Foods. Foodborne pathogens and disease [Internet]. 2014, 0(9), 1-4.

[2] Calicioglu, M.; Sofos, J.N.; Kendall, P.A. Influence of marinades on survival during storage of acid-adapted and nonadapted Listeria monocytogenes inoculated postdrying on beef jerky. International Journal of Food Microbiology. 2003, 86(3), 283292.

[3] Zhou, G.H.; Xu, X.L.; Liu, Y. Preservation technologies for fresh meat - A review. Meat Science [Internet]. 2010, 86(1), 119-128.

[4] Beuchat, L.R.; Komitopoulou, E.; Beckers, H.; Betts, R.P.; Bourdichon, F.; Fanning, S.; Joosten, H.M.; Ter Kuile, B.H. Low-Water Activity Foods: Increased Concern as Vehicles of Foodborne Pathogens. Journal of Food Protection [Internet]. 2013, 76(1), 150-172. 
[5] Von Gersdorff, G.J.E.; Crichton, S.O.J.C.; Retz, S.K.; Hensel, O.; Sturm, B. Drying of fresh organic beef with different pretreatments. In: The 20th International Drying Symposium (IDS 2016), Gifu, Japan. 2016.

[6] von Gersdorff, G.J.E.; Porley, V.E.; Retz, S.K.; Hensel, O.; Crichton, S.O.J.; Sturm, B. Drying behavior and quality parameters of dried beef (biltong) subjected to different pre-treatments and maturation stages. Drying Technology. 2018, 36(1), 2132.

[7] Rayaguru, K.; Routray, W. Mathematical modeling of thin layer drying kinetics of stone apple slices. International Food Research Journal. 2012, 19(4).

[8] Crichton, S.; Shrestha, L.; Hurlbert, A.; Sturm, B. Use of hyperspectral imaging for the prediction of moisture content and chromaticity of raw and pretreated apple slices during convection drying. Drying Technology. 2017, 0(0), 1-13.

[9] Crichton, S.O.J.; Kirchner, S.M.; Porley, V.; Retz, S.; von Gersdorff, G.; Hensel, O.; Sturm, B. High $\mathrm{pH}$ thresholding of beef with VNIR hyperspectral imaging. Meat Science. 2017, 134, 14-17.

[10] Retz, S.; Porley, V.E.; von Gersdorff, G.; Hensel, O.; Crichton, S.; Sturm, B. Effect of maturation and freezing on quality and drying kinetics of beef. Drying Technology. 2017, 35(16), 2002-2014.

[11] Traffano-Schiffo, M.V.; Castro-Giráldez, M.; Fito, P.J.; Balaguer, N. Thermodynamic model of meat drying by infrarred thermography. Journal of Food Engineering [Internet]. 2014 [cited 2016 Jan 25], 128, 103-110.

[12] Martens, H.; Stabursvik, E.; Martens, M. Texture and Colour Changes in Meat during Cooking Related to Thermal Denaturation of Muscle Proteins. Journal of Texture Studies. 1982, 13(3), 291-309.

[13] Tornberg, E. Effects of heat on meat proteins - Implications on structure and quality of meat products. Meat science [Internet]. 2005 [cited 2016 Feb 22], 70(3), 493-508.

[14] Lee, S.W.; Kang, C.S. Effects of moisture content and drying temperature on the physicochemical properties of ostrich jerky. Nahrung - Food. 2003, 47(5), 330-333.

[15] Chou, S.K.; Chua, K.J. On the study of the drying behavior of a heat-sensitive biomaterial undergoing stepwise-varying temperature schemes. Industrial \& engineering chemistry research. 2003, 42(20), 4939-4952.

[16] King, N.; Whyte, R. Does it look cooked? A review of factors that influence cooked meat color. Journal of Food Science. 2006, 71(4), R31-R40.

[17] Wu, D.; Wang, S.; Wang, N.; Nie, P.; He, Y.; Sun, D.W.; Yao, J. Application of Time Series Hyperspectral Imaging (TS-HSI) for Determining Water Distribution Within Beef and Spectral Kinetic Analysis During Dehydration. Food and Bioprocess Technology. 2013, 6(11), 2943-2958. 